\title{
ACCOMPANIMENT MODEL OF INTEGRATIVE CREATIVE ECONOMIC FOR TAX COMPLIENCE
}

\author{
Jeni Susyanti \\ Siti Aminah \\ Faculty of Economic And Business, Islamic University of Malang (UNISMA), \\ Indonesia
}

\begin{abstract}
Taxation is the primary source of income for a state. The purpose of this research to know the model of creative economic assistance, identification of income share, tax training action. This research includes descriptive research using qualitative methods. To analyze the data of researchers using Miles and Huberman theory through data reduction, data presentation, draw conclusions. The result of the research shows that it is necessary to assist the business of the creative economy in the field of accounting and taxation in integrative model. There is a share of revenue earned. Action expansion of tax training, to improve taxpayer compliance. The model test is done by analysis on an aspect of recording, business bookkeeping, fulfillment of tax obligation. A quad helix action model is required for creative economic assistance.
\end{abstract}

Keywords: integrative model, creative economic, tax complien. 


\section{INTRODUCTION}

Entrepreneur amount increase from creative economic class does not make a big change to tax deposit amount to Government. Based on the result of the research from PHB Susyanti (2014). Respondents categorized as very good with score 4,20 - 5,00 in developing creative economy business, but the awareness of the duty to pay tax also enter the bad category with score 1,81 -2,60, according to Tarigan opinion (2012).

Based on result of research by PHB Susyanti (2016) in the field of tax, there are 40 creative economy performer $(87,0 \%)$ replies that implies them not really understand general condition of tax that applies so that make difficult to do the right selfassessment system, 42 creative economic in tourism sector $(91,3 \%)$ that replies voluntary compliance of taxpayer does not create yet so that makes them not obey the tax system that applies.

Remembering the awareness and compliance of taxpayer is an important factor to increase tax income, so to reach tax target, it is needed to grow the awareness and compliance to fulfill the obligation to pay the tax as with the current tax system (Mustikasari, 2007:3). Creative economy can give the benefit to the business performer and have a potential increase Nation tax income in tax sector, that makes it need proper intensive research about tourism creative economy accompaniment model integratively to increase the compliance to the taxpayer. The purpose of this research is to know the model of creative economy accompaniment doing share income acquisition identification, profit acquisition identification, training action about taxation to the creative industry. While the scope of research aimed to tourism creative economy business performer, especially outdoor tool creative economy performer and from this research we expected to get the depiction of compliance of taxpayer from creative economy performer, and from that compliance are expected to an increase of income from tax sector that in the end supporting tourism sector of Malang Raya.

\section{THEORETICAL BACKGROUND}

Creative economy as the concept that prioritize information and creativity with relying on idea and knowledge from their human resources in their ecnonomy activity. Howkins 
(2001) mentioned that the new economy has appeared around creative economy controlled by intellectual property law like patent, copyright, brand, royalty and design. To move creative industry required some supporting factors, among them are educational direction, good perception to tax system effectivity, giving awards to creative person, and make conducive business climate (Anggraeni, 2008).

According to research by Widayati and Nurlis (2010) there are some factors that influencing the taxpayers to pay their tax obligation, that is awareness factor to pay the tax, good perception of tax system effectivity, knowledge and understanding about tax regulations.

Increasing number of enterpreuners from creative economy group, evidently not make a big change to the amount of tax deposit income to government (Susyanti, 2015). The lack of awareness and obedience of creative economy business performer is not because their unwillingness to pay the tax, but because their lack of understanding to tax obligation. Most of tourism creative economy business performer in Malang already know their tax obligation, but not yet fulfill their obligation (Susyanti, 2014).

Tax compliance according to Nurmantu (2003:148) can be defined as some situation where taxpayers fulfill their tax duty and do their taxtation rights. And according to Finance Minister's ministerial decree Number 544/KMK.04/2000 stated that "Tax compliance are taxpayers action to fulfill their tax obligation in accordance with statutory provisions and taxation regulations that applicable in the country".

Quadruple Helix is the development from Triple Helix with integrating civil society with innovation and knowledge (Oscar, 2010). Quadruple Helix Innovation Theory is collaboration from four sectors, stands for: government, business, academics and civil society that have a role to encourage innovation to grow.

Triple Helix is a sector that can make the general community to increase creativity, idea, and skills (Etzkowitz, 2008). Literature studies before are the collaboration between academics, government, company and civil society that can encourage motivation for the creative community to help grow economy rates (Oscar, 2010)

On the other hand, development in ASEAN Economic Community (AEC) triple helix interaction is not enough yet, but in need of specific integration with creative economy community in quad helix model which is synergy and partnership from government, privates and intellectuals (expert team from academics and public) and quad-helix 
collaboration between government, privates, intellectuals and creative community are more suitable to applied for now. (Mulyana, Sutapa, 2010). Creative Industry has a contribution to the economy building, quadruple helix (intellectuals, government, business, civil society) have a significant effect on creativity.

\section{METHOD, DATA AND ANALYSIS}

\section{Approach Research}

This research has come under the kind of descriptive research, mean to explore and clarifies about some phenomena or social reality, by describing some variable that related to the problem and researched object. This kind of descriptive research does not use and conduct hypothesis examination, so does not intend to build and develop the theory (Faisal, 2010). Phenomena will be described with systematic, factual and accurate in this research is the model of tourism creative economy accompaniment with integrative to increase compliance of taxpayer.

\section{Population and Sampling Technique}

Population in this research includes all of the creative economy business that produces and sell outdoor tools and creative industry in the same field, in 46 businessmen. According to Arikunto (2006), this research does not take a sample, but the whole of them are investigated.

\section{Type of Data and Source}

In this research the data are divided into two kinds, primary and secondary (Indriantoro and Supomo, 2002). Primary data is respondents opinion, including accounting policy, tax administration, accompaniment, and business training model synchronization and tourism creative economy performer condition in order to increase di compliance of the taxpayer. And secondary data is obtained data that obtained indirectly, already available and written by another party including proofs, notes, and historical reports. This data obtained from the Department of Industry and Commerce in form of name and address of tourism sector creative economy business performer, its business kind, and the number of the employees. Besides that, it can be obtained from the office where the tourism sector creative economy business located, in form of the business profile and kind of its activities. 


\section{Data Collecting Technique}

Primary data collecting technique is gathered by giving a questionnaire, interview with the respondent in research filled and doing a direct observation of the object to make sure validation of obtained data with questionnaire and interview. While the secondary technique with recording or photocopying the related data with its business profile and kind of works.

Based on the respondent answer it can be measured the distribution of respondents answer frequently until is known if the management of the creative economy business is going well (showed by high score) or not going well (showed by bad score). To decide it's going well or not, according to Tarigan (2012) it is decided by the highest score range minus the lowest score divided by the amount of the answer category, then respondent perception level measured by the average score of the respondent answer, as shown above:

\begin{tabular}{|c|c|c|}
\hline No & $\begin{array}{c}\text { The range of respondent } \\
\text { average score }\end{array}$ & $\begin{array}{c}\text { Level of respondent } \\
\text { perception }\end{array}$ \\
\hline 1. & $1,00-1,80$ & Very Bad \\
\hline 2. & $1,81-2,60$ & Bad \\
\hline 3. & $2,61-3,40$ & Good \\
\hline 4. & $3,41-4,20$ & Very Good \\
\hline 5. & $4,21-5,00$ & Excellent \\
\hline
\end{tabular}


According to Miles and Huberman (1992), the steps to analyze the data with qualitative explained in the picture below:

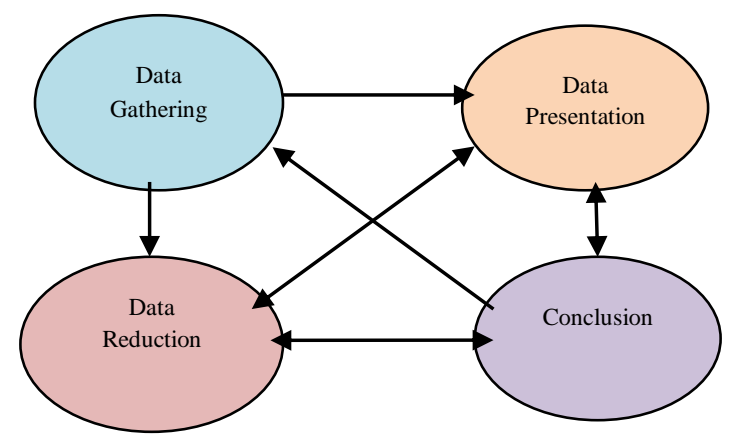

Picture 1

Data Analysis Model

From the picture above, it can be explained that the researcher should move between four point's "axis", moving between reduction, presentation, and conclusion for the rest of research time. Data coding, reduction pointing to the new idea to be included in the matrix (data presentation). Data recording require data reduction, etc.

After matrix is filled, an early conclusion can be taken. Qualitative data analysis is a continuous effort, and data reduction, data presentation, and conclusion become a depiction of success in sequence as a series of analysis that following each other.

\section{RESULT AND DISCUSSION}

\section{Accompaniment to Creative Economic Business Entrepreneur in Accounting} and Tax integrative model

Using Miles and Huberman's analysis model, according to questionnaire data and interview, obtained information that creative economy business performer has a good perception with score 4.4 in bookkeeping to know the profit, doing self-bookkeeping with average score 4.3 and want discipline administration effort with average score 4.4 the good perception level that is taking simple notes for sales (manual) with average respondent's answer at 3.9 and taking simple notes for cost with average score 3.8 The good perception level that is computerized sales notes taking with 
average score 2.6 and computerized cost notes taking with average score 2.8 .

According to the questionnaire answer and interview in the tax, sector obtained information that creative economy business performer has good perception level with score 3.8 in knowing tax obligation and in need of business assistance with score 3.9. Good perception with score 3.0 in knowing how to fill letter of notification and have the employee to help in bookkeeping with score 3.1. Bad perception with score 2.6 to having the employee to help in tax administration.

Integrative creative economy accompaniment model in tourism sector is required to creative economy business performer to fulfill the tax obligations in deposit, reporting, and bookkeeping, and in the end will affect the taxpayer in their obligation to pay the tax, with the purpose to increase nation's income to the use for prosperity to all people in Indonesia. Integration model that according to be applied as these examples:

1. Accompaniment model for integrative creative economy business tourism sector management that is the creative economy building which under intellectual, business government, community, broadcat and Social Media.

2. Intellectuals here are represented by the university that has the role of a supporter to born the new idea and knowledge that is the source of creativity and the birth of Indonesians creativity potential. University activities, with research and social service, can give accompaniment and training how to fulfill the tax obligation through bookkeeping, deposit, and tax obligation report.

3. The business that is the business performer who can make creativity into something that has an economic benefit, from the financial side, marketing, production, and another field.

4. Government as a facilitator and regulator, as the main actor of the creative economy mover, to make sure that the creative industry can grow and develop. From socialization, account representative service, and information provider from online and offline mass media.

To make sure creative economy tourism sector can grow optimally, giving profit to the performer and have potential to increase nation's tax income, coaching is needed to the existence of creative economy tax sector, such as in socialization from Directorate General of Taxation, counseling from account representative. Attending 
workshop, seminar that held by competence organization in taxation. As from University can help from social service. Creative Economy Organization that held by the government to touch up and accommodate creative economy business performer, such as with supplying intensive government help. Integrative creative economy business accompaniment model development is needed to increase the obeying of the taxpayer.

\section{Creative Economy Business Income Identification Share is not relevant yet, income potential not offset by a tax income increase}

Creative economy business performer in Malang Raya which moved by young can be identified according to from income share every month. After field research to creative economy performer, acquired information that creative economy business in Malang Raya is very potent, it can be seen at outdoor equipment sell rate that increases near August, hiking season. This thing also supported by the statement of store sales promotion Consina Erwin Prasetyo (Jawa Pos, Tuesday $21^{\text {st }}$ of June 2016). Some outdoor equipment stores in Malang recorded sale increase at 40 percent. Jacket, pants, shirt and mountain sandals are the most sought thing at outdoor equipment store.

Miles and Huberman analysis data model that used with data gathering process with questionnaire and interview, data reduction, data presentation and conclusion taking become conception of success sequence as a serial of analysis activities, obtained analysis result that most of the creative economy is moved by youngsters and small entrepreneur company. This sector has a big potential that can be the big power to make Malang become tourism and education city.

But the big potential is not balanced by tax income increase, this is not because the entrepreneur doesn't want to pay the tax, but like other small companies, most of them are not knowledgeable enough about tax. This revealed from the question: "Is there any right sales data to specify how much is the debted tax based on PP 23/2018, and the correspondent answered there are not exact sales data to measure debted tax based on PP 23 / 2018 at 31.6\%. And also to the question: "Is there any adequate employees or staffs in carrying out the company's tax obligation and duty, most of them responded that they don't have it at $57.7 \%$. 


\section{Expansion Action: Tax Training for raising tax obligation awareness}

Taking action to held tax training for raising tax obligation awareness after seeing creative economy business performer's bad perception at tax comprehension gathered from questionnaire answer and respondents interview with score between 1.9 to 2.0 to statement active tax counting based on self assessment system, do the bookkeeping with the stated clause, counting and balancing the tax with the stated clause, do the debted tax, pay the tax in time, do not have tax debt in any kind of tax, fill the Annual Letter of Tax right and clear. So, the tourism creative economy business that knows most of the time that does not have tax awareness can be known. Based on document studies like sales record and purchase record, $70 \%$ of creative economy business performers have simple notes. As for financial statements making as the obligation for creative economy business performer's personal tax with income $\mathrm{Rp} 4.800 .000 .000$,- above and board taxpayer almost $50 \%$ of the creative economy performer does not fulfill the condition. Based on the analysis above it can be predicted that most of the creative economy performers still confused how to report, deposit and make tax administration. Therefore, complete and detail understanding about tax especially PP-23/2018 that order out the tax for a small company is needed, where tourism creative economy business performer that does not have gross business circulation below 4.8 billion rupiahs in one year tax is bearing final income tax with $1 \%$ rates as explained in PP-23/2018

Based on that understanding tourism creative economy business performer that does the business in Malang that run by individuals or entities, if already fulfill subjective and objective requirement it is obligated to have and register a tax ID number and must obey to tax obligation in Indonesia. Besides the job to run self-assessment (taxpayers gave trust to count, deposit and report the tax obligation by themselves) the taxpayers are obligated to cut and collect the tax (Susyanto \& Dahlan, 2015).

Tax Training Action Expansion intended to increase knowledge and tax skill to taxpayers. Tax training is given by combining theory and practice in shape of inhouse training in company and open to public that followed by general public, consist of : Income Tax Training, Value-adding Tax Training, Tax General Requirements, Property Tax and Revenue Stamp, Legislation General Requirements and Tax Law, Tax on Special Industry, Tax Accounting, Current Problems on Tax. 
Trials are done with analysis on some aspects; recording, bookkeeping, tax obligations fulfilling. This remembers that accounting system, bookkeeping, and accounting are inadequate, as the respondents answer at 54,3\% where transaction recording only in sales. In general, recorded transactions are only from cash inflows, but the cash outflows are not noticed enough. As for transaction on production section and the others that do not record yet. Administration system, bookkeeping, and accounting are not sufficed yet, it can make some sector have difficulty to count how much is the real profit gained and sales transaction recording are not in accordance and amount of obligated tax from central government or local government.

\section{CONCLUSION}

1. Integrative creative Economy Business Performer accompaniment in accounting and tax with triple helix model.

2. Creative economy business performer income share identification is not relevant, creative economy business performer income potential cannot be balanced with tax income increase.

3. Tax training expansion action, to increase taxpayer's compliance

\section{IMPLICATIONS}

1. Expansion from triple helix model to the quad helix, with giving space for creative economy business performers creativity.

2. (Level of compliance to pay the tax is still low). Therefore, in the future, related parties with tax should do workshop or socialization in connection with tax over the tourism creative economy business performer.

3. Detailed and complete understanding of tax especially PP-46/2013 that manage about tax for small companies are necessary.

The limitation of this study is that the data collection used is only questionnaires based. It means that this research only covered the perceptions of respondents and did not describe the actual situation of respondents. This study also used a limited sample, so the results cannot be generalized. Future research should be done in another type of business and variables. 


\section{REFERENCES}

Anonymous, Departemen Perdagangan Republik Indonesia, Pengembangan Ekonomi Kreatif Indonesia 2025.WWW.Deperindag.go.id.

Undang-undang Republik Indonesia Nomor 28 Tahun 2007 Tentang

Perubahan Ketiga Atas Undang-undang Nomor 6 Tahun 1983 Tentang Ketentuan

Umum dan Tata Cara Perpajakan Undang-Undang Republik Indonesia Nomor 36 Tahun 2008Tentang

Perubahan Keempat Atas Undang-UndangNomor 7 Tahun 1983 Tentang Pajak Penghasilan.

Anggraeni, Nenny. Industri Kreatif. Jurnal ekonomi, desember 2008, volume XIII No.3.

Arikunto, Suharsini. 2008. Prosedur Penelitian Suatu Pendekatan Praktik. Cetakan kesembilan. Rineka Cipta. Jakarta.

Etzkowitz, H \& Dizisah, J. (2008). Triple Helix Circulation : the heart of innovation and development, International Journal of Tecnology Management and Sustainable Development, 7(3), 101-115.

Howkins, John.2001. Creative Economy, How People Make Money from Ideas. Penguin

Indriantoro, Nur dan Bambang Supomo. 2002. Metodologi Penelitian Bisnis Untuk akuntansi \& management, BPFE. Yogyakarta.

Miles, Matthew B dan A. Michael Huberman. 1992. Analisis Data Kualitatif. UI Press. Jakarta.

Mustikasari, Elia. 2007. Kajian Empiris tentang Kepatuhan Wajib Pajak Badan di Perusahaan Industri Pengolahan di Surabaya.Simposium Nasional Akuntansi X. Makassar.Hal.1-41.

Oscar. A., S. Monterino., \& M. Thomshon. (2010).A Growth Model for the Quadruple Helix Innovation Theory, Journal of Business Economics and Management, 13(4), 1-31. 
Susyanti, Jeni dan Ahmad Dahlan. 2015. Perpajakan Untuk Akademisi dan Praktisi. Penerbit: Empat Dua media (Kelompok Intrans Publishing) Malang.

Susyanti Jeni. 2014. Problems Identification Of Creative Economy Business Actors Of Tourism Sector In Malang City in Effort to Meet Tax Obligations. International Journal of Business and Management Invention (IJBMI), Volume 3 Issue 11.

Susyanti Jeni. 2016. Pemetaan Problematika Bisnis Ekonomi Kreatif Sektor Wisata Dan Model Pendampingan Terintegrasi Untuk Meningkatkan Kepatuhan Wajib Pajak. Prosiding Forum Manajemen Indonesia (FMI) ke 8 Palu.

Suryana, Anandita Budi. 2013.Pegawai Direktorat Jenderal Pajak Branchless untuk Kemudahan Pembayaran Pajak UKM. www.pajak.go.id. Rabu, 6 Maret 2013.

Tarigan, Yuike Arianti. 2012. Pengaruh Motivasi Kerja Terhadap Efektivitas Kerja Pegawai Pada Kantor Dinas Kehutanan Propinsi Sumatera Utara. SKRIPSI. Departemen Ilmu Administrasi Negara Fakultas Ilmu Sosial dan Ilmu Politik Universitas Sumatera Utara. 